\title{
DETECTION AND MORPHOLOGIC ANALYSIS OF POTENTIAL BELOW-CANOPY CAVE OPENINGS IN THE KARST LANDSCAPE AROUND THE MAYA POLITY OF CARACOL USING AIRBORNE LIDAR
}

\author{
John F. Weishampel ${ }^{*}$, Jessica N. Hightower ${ }^{1}$, Arlen F. Chase ${ }^{2}$, Diane Z. Chase ${ }^{2}$, And \\ RyAN A. PATRICK ${ }^{3}$
}

\begin{abstract}
Locating caves can be difficult, as their entranceways are often obscured below vegetation. Recently, active remote-sensing technologies, in particular laser-based sensor systems (LiDARs), have demonstrated the ability to penetrate dense forest canopies to reveal the underlying ground topography. An airborne LiDAR system was used to generate a $1 \mathrm{~m}$ resolution, bare-earth digital elevation model (DEM) from an archaeologically- and speleologically-rich area of western Belize near the ancient Maya site of Caracol. Using a simple index to detect elevation gradients in the DEM, we identified depressions with at least a $10 \mathrm{~m}$ change within a circular area of no more than $25 \mathrm{~m}$ radius. Across $200 \mathrm{~km}^{2}$ of the karst landscape, we located 61 depressions. Sixty of these had not been previously documented; the other was a cave opening known from a previous expedition. The morphologies of the depressions were characterized based on the LiDAR-derived DEM parameters, e.g., depth, opening area, and perimeter. We also investigated how the measurements change as a function of spatial resolution. Though there was a range of morphologies, most depressions were clustered around an average maximum depth of $21 \mathrm{~m}$ and average opening diameter of $15 \mathrm{~m}$. Five depression sites in the general vicinity of the Caracol epicenter were visited; two of these were massive, with opening diameters of $\sim 50 \mathrm{~m}$, two could not be explored for lack of climbing gear, and one site was a cave opening into several chambers with speleothems and Maya artifacts. Though further investigation is warranted to determine the archaeological and geological significance of the remaining depressions, the general methodology represents an important advancement in cave detection.
\end{abstract}

\section{INTRODUCTION}

Caves have biological, geological, hydrological, and often, when near settlements of ancient cultures, anthropological significance. The detection of cave openings, classification of cave types, and mapping of cave morphologies are initial steps in documenting and conserving these sites of natural and cultural heritage. However, many caves in mesic regions remain undocumented, as the openings are often obscured by vegetation. This is especially common in Mesoamerica, where dense, structurally-complex rainforest canopies overtop numerous Maya archaeological sites (Ricketson and Kidder, 1930; Chase, 1988).

Caves are believed to have played a significant role in ancient Maya societies (e.g., Brady and Prufer, 2005; Prufer and Brady, 2005) from about 2500 BC to AD 1500. As portals to the Maya underworld, Xibalbá, caves served as places of religious and mythological importance in addition to functioning as shelters. They were sites of rituals, ceremonies, and burials, and they hence often contain ceramics, artwork, architectural modifications, and skeletal remains (e.g., Moyes, 2002). However, like many of the archaeological features found in the Maya polities, cave entrances are often covered by the dense tropical rainforest vegetation that reemerged after the settlements were abandoned roughly a thousand years ago.

There are several possible ways to locate caves using remote sensing. On the ground, covering a limited area, ground penetrating radar can be used to detect caves (Sellers and Chamberlain, 1998). However, the extensive below-ground root mass and the density of the aboveground vegetation preclude the use of GPR in a rainforest environment. For broad-scale prospecting, airborne- or satellite-based remote sensing is necessary. Because caves have a more stable temperature than the surface environment, there has been an effort to use thermal remote sensing on earth (Griffith, 2000) and on other planets (Cushing et al., 2007; Wynne et al., 2008) to detect cave openings. Though a temperature gradient of $7.2{ }^{\circ} \mathrm{C}$ was detected on the ground 50 to $100 \mathrm{~m}$ away from cave

\footnotetext{
*Corresponding Author, jweisham@mail.ucf.edu

${ }^{1}$ Department of Biology, University of Central Florida, Orlando, FL 32816, USA

${ }^{2}$ Department of Anthropology, University of Central Florida, Orlando, FL 32816, USA

${ }^{3}$ Interdisciplinary Studies Program, University of Central Florida, Orlando, FL 32816, USA
} 

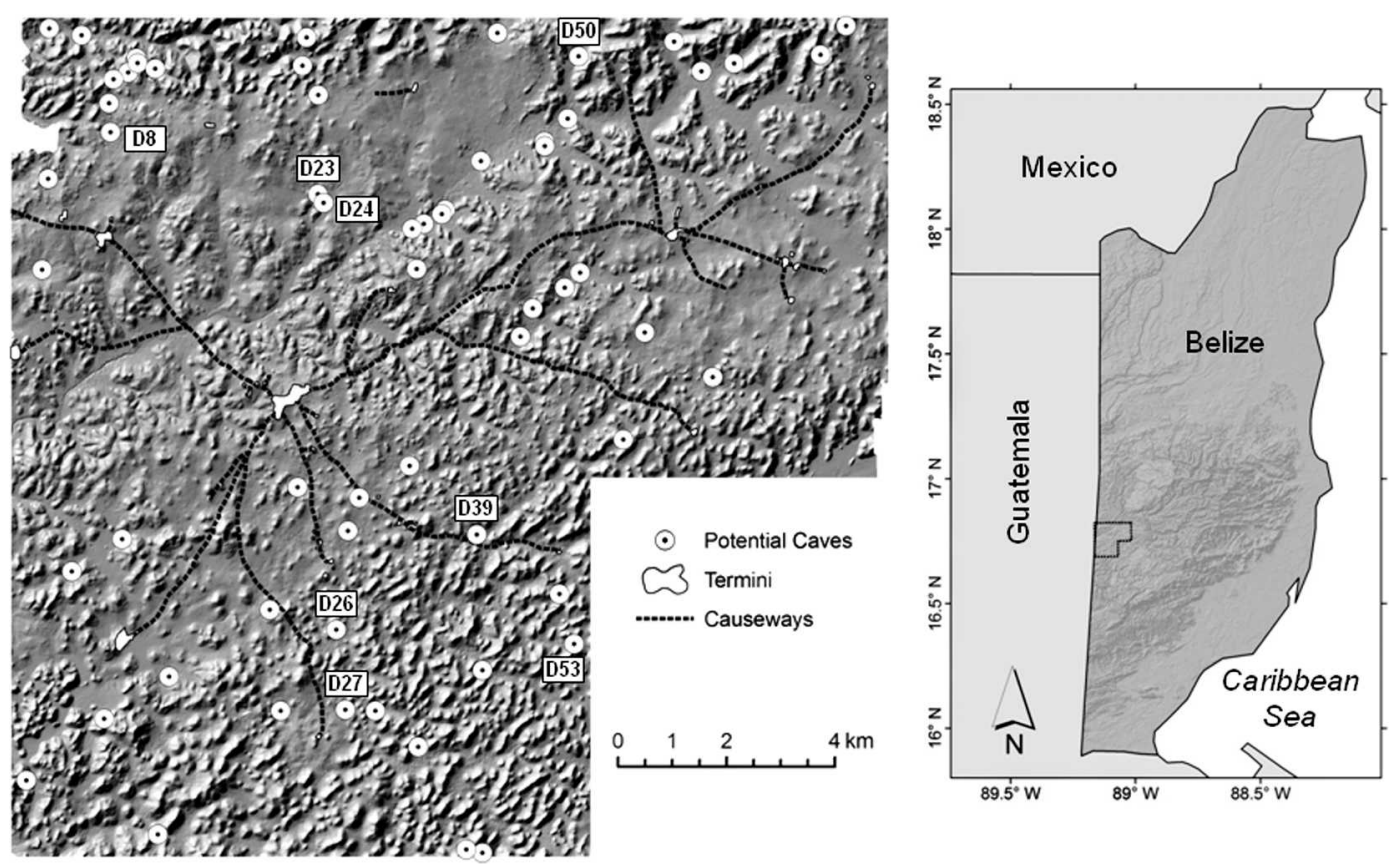

Figure 1. At right, location of $200 \mathrm{~km}^{2}$ study area on the western border of Belize on the Vaca Plateau, shown on the hillshaded Shuttle Radar Topography Mission image of Belize. The expanded study area shows the 61 depressions more than $10 \mathrm{~m}$ deep on the hillshaded bare-earth image from the airborne LiDAR-derived DEM. Numbers refer to depressions specifically mentioned in this paper.

openings in Belize (Griffith, 2001), this method is challenging, given the coarse resolution of most satellite thermal sensors. Furthermore, even with finer airborne or hyperspatial satellite sensors, the sharp microclimate gradient in closed-canopy tropical rainforest regions from the ground to the upper surface of the forest canopy 20 to $30 \mathrm{~m}$ above may mask the temperature at the cave opening (Allee, 1926). Griffith (2001) also used an active form of remote sensing (Star 3i RADAR) to detect depressions in the surface topography of the forest canopy (Weishampel et al., 2000a) that may correspond to depressions or cave openings. This proved successful for a large $\sim 25 \mathrm{~m}$ wide sinkhole, but not for depressions below the spatial resolution of the sensor. Given the ability of another active form of remote sensing (LiDAR - Light Detection and Ranging) to penetrate dense forest cover to measure ground surfaces (e.g., Weishampel et al., 2000a, 2000b; Hofton et al., 2002; Gallagher and Josephs, 2008), we assessed its ability to locate known and unknown potential cave openings and to quantify the geomorphology of their entranceways.

As part of an archaeological prospecting study (Weishampel et al., 2010), we used airborne LiDAR to map unknown Maya structures such as temples, causeways, and monuments in a $200 \mathrm{~km}^{2}$ area around Caracol, Belize (Chase et al., 2010). In addition to anthropogenic features in the $1 \mathrm{~m}$ horizontal resolution digital elevation model (DEM), we identified numerous vertical depressions and surface openings. These were thought to represent cave openings, pits collapse dolines, or chultuns (subterranean storage chambers) that, if contemporaneous, could have been used by the ancient Maya. Here, we report our approach and findings.

\section{Caracol Study Area}

The geology of the Yucatán Peninsula consists of a porous limestone shelf that is honeycombed with sinkholes, cenotes, underground streams, lakes, and caverns. Estimated to cover about $170 \mathrm{~km}^{2}$, Caracol is the largest Maya archaeological site in Belize. Located near the Guatemala border on the Vaca Plateau of the Cayo District (Fig. 1) west of the Maya Mountains, the Caracol landscape consists of rolling karst-defined hills and valleys ranging from about 300 to $700 \mathrm{~m}$ in elevation. At its cultural peak (ca. AD 700), the metropolitan population is estimated to have been greater than 100,000, which makes it one of the most populous cities in the Pre-Columbian world (Chase and Chase, 1996). Since 1950, $23 \mathrm{~km}^{2}$ have been painstakingly surveyed on the ground (Chase, 1988; Chase and Chase, 2001). The main acropolis, comprising numerous large buildings, is at the center of several causeways that radiate outward to smaller areas called termini that also possess high concentrations of building structures.

Presently most of the remains of Caracol are hidden in the subtropical moist forests of the Chiquibul National Park (Brokaw, 1992). The average canopy height is about $25 \mathrm{~m}$, with a few emergent trees extending to over $35 \mathrm{~m}$. 
The vertical forest structure is fairly homogeneous, with no distinct layers.

In the greater vicinity of Caracol, outside the $200 \mathrm{~km}^{2}$ area, numerous caves have been located (Miller, 1990) and many of these are of archaeological note (McNatt, 1996; Reeder et al., 1998). The Río Frío complex $26 \mathrm{~km}$ to the north-northeast of the center, the Quiroz Cave $13 \mathrm{~km}$ to the northeast, Actun Balam $15 \mathrm{~km}$ to the southeast (Pendergast, 1969, 1970; Pendergast and Savage, 1971), and several other caves 30 or more $\mathrm{km}$ to the northeast (Moyes, 2002) all contained artifacts such as bones and pottery that indicated that they were sites of ritual use. Feld (1994) documented nine caves within the $200 \mathrm{~km}^{2}$ Caracol area; most are within $3 \mathrm{~km}$ of the center. Many of these have small openings and deep shafts. Most of these are thought not to have been accessible to or not contemporary with the ancient Maya, meaning that the openings are more recent. Hence, only a few of these caves contain artifacts.

\section{Methods And Materials}

At the end of April 2009, during the end of the dry season, the National Center for Airborne Laser Mapping (NCALM; Carter et al., 2001) flew their LiDAR system, which consisted of an Optech, Inc., Gemini Airborne Laser Terrain Mapper with onboard GPS and Inertial Measurement Unit systems on board a Cessna 337 Skymaster. The timing of the flight was designed to correspond roughly to the height of leaf abscission for this forest. However, leafoff typically does not exceed $20 \%$ at any time of the year, as most tree species maintain leaves all year long (Brokaw, 1992).
The NCALM system records four returns per pulse as it scans across a $0.5 \mathrm{~km}$ swath; when a pulse is transmitted, part of the pulse initially reflects off an object closest to the aircraft, usually the canopy, while the remainder of the pulse continues through gaps in the canopy, reflecting off other plant surfaces and in some cases the ground. The laser pulse rate is $167 \mathrm{kHz}$, and the scan rate is $28 \mathrm{~Hz}$. At a nominal above-ground altitude of 600 to $1000 \mathrm{~m}$, the system yields 10 to 15 laser shots per square meter with a height accuracy of 5 to $10 \mathrm{~cm}$ (one sigma) and a horizontal accuracy of 25 to $40 \mathrm{~cm}$ (one sigma). This system also records the relative intensity of each return. By crisscrossing (east-west and north-south) flight lines over the central Caracol area (Chase et al., 2010), 20 to 30 shots per square meter were obtained, yielding a more accurate digital elevation model.

Of the more than 20 laser shots $/ \mathrm{m}^{2}$, an average of 1.35 points $/ \mathrm{m}^{2}$ penetrated through canopy gaps to reach the ground. NCALM researchers interpolated these points to generate a $1 \mathrm{~m}$ resolution DEM. The DEM file for the entire $200 \mathrm{~km}^{2}$ area was $65 \mathrm{MB}$ and was analyzed using offthe-shelf software or freeware on a standard (circa 2010) desktop computer. From the bare-earth DEM rendered with a hillshade algorithm (Fig. 1), we visually identified thousands of unknown Maya settlement structures and some obvious steep surface depressions. LiDAR at Caracol has proven very effective for detecting man-made archaeological features below the canopy (Chase et al., 2010; Chase et al., 2011).

Using the Topographic Position Index (TPI) (Guisan et al., 1999) calculator within the Land Facet Corridor Designer software (Jenness et al., 2010), a plug-in application for ArcGIS (v. 9.3), we further identified numerous a)

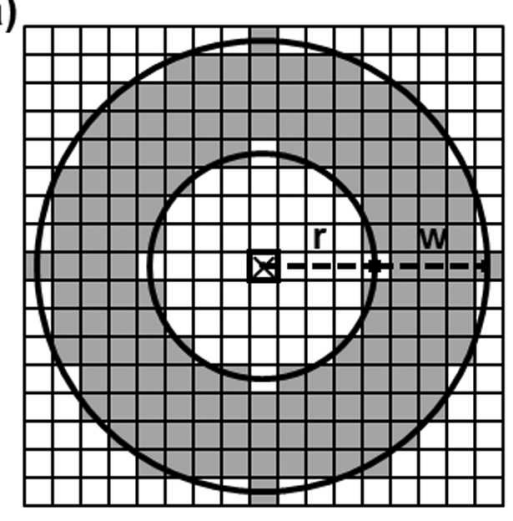

b)

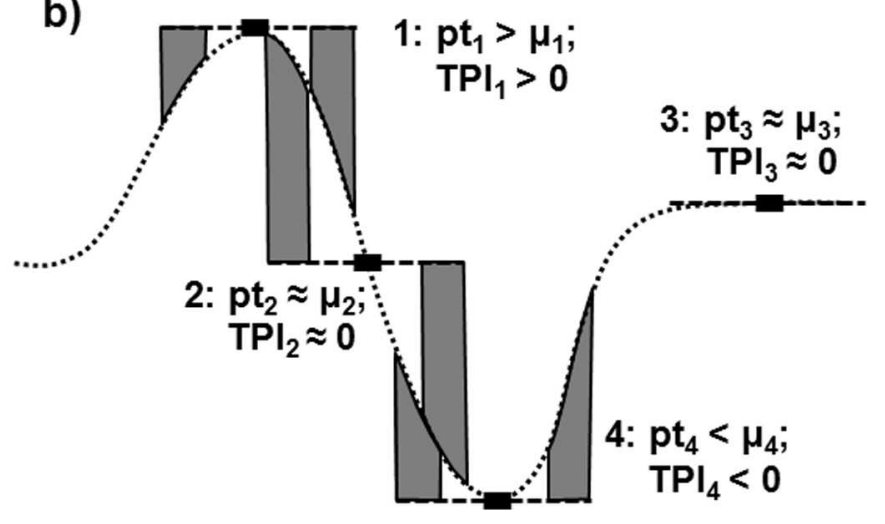

Figure 2. (a) Topographic Position Index (TPI) annulus filter that was applied to the DEM. It calculates the difference between the elevation of the focal cell $(p t)$ designated with the ' $x$ ' and the average elevation of the gray cells $(\mu)$ in the ring surrounding it. Two parameters that can be adjusted are the inner radius ( $r$ ), the distance from the center of the focal cell to the inner edge of the ring, and the annulus thickness (w), the difference between the inner and outer radii. (b) An example of a topographic cross section shows the four main terrain scenarios: 1 , hump or hilltop; 2 , slope; 3, level or flat; 4, depression or valley, and the associated $\mathrm{pt}, \mu$, and TPI values. The gray bars depict the elevations at the sides of the annuli with respect to the elevations of the focal cells (adapted from Weiss, 2001 and Jenness et al., 2010). Terrain scenarios 2 (slope) and 3 (level) are distinguished by evaluating the overall slope in the annulus. 

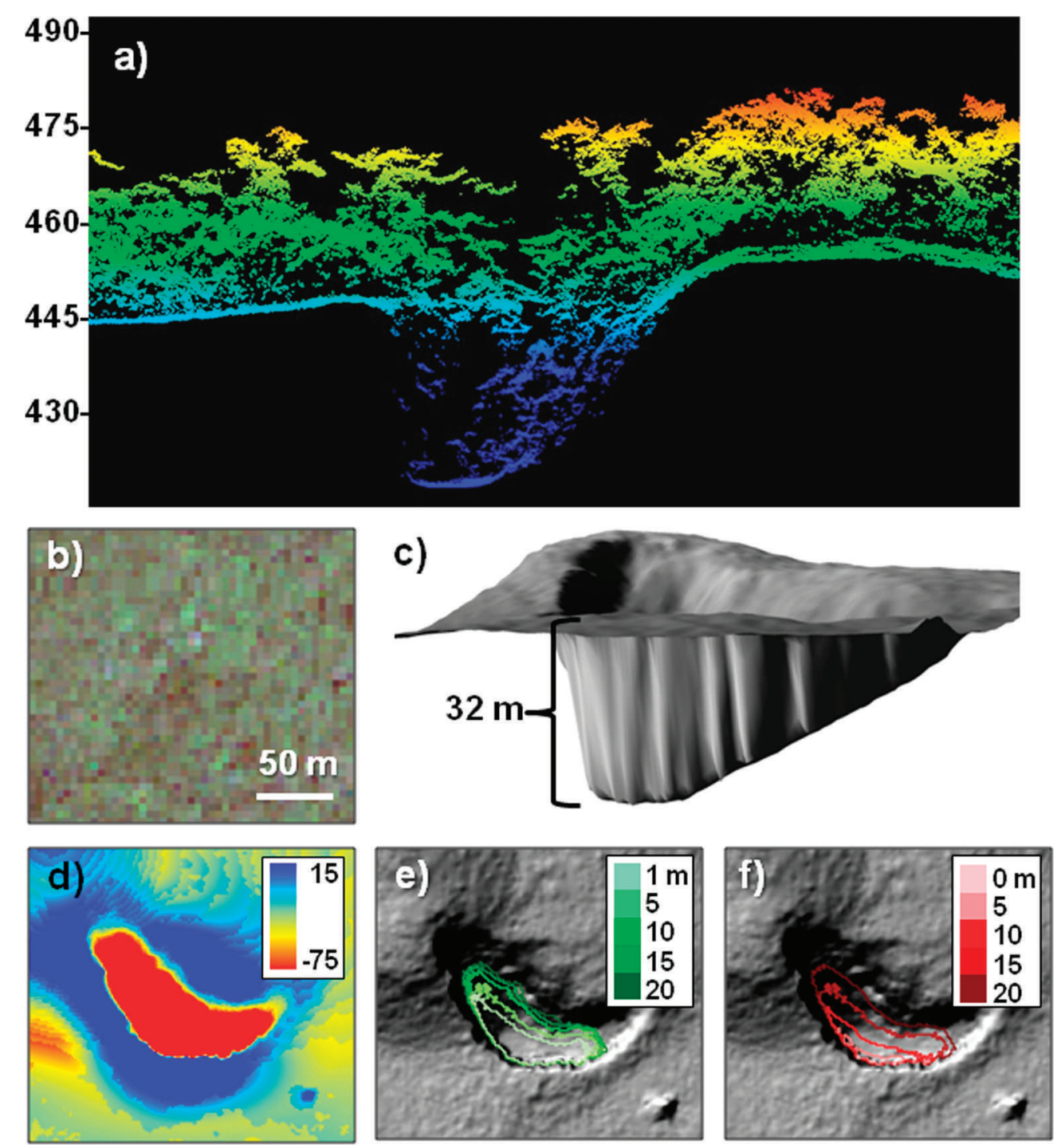

Figure 3. (a) LiDAR point-cloud data depicting forest canopy and ground surface at depression 24 . The values are meters above sea level. (b) Top-down view provided by the IKONOS satellite shows complete canopy coverage over the depression. (3) 3-D rendering of the LiDAR image with vegetation removed. (d) TPI image depicting relative elevation in meters. (e) The perimeter of the area with TPI value $-\mathbf{1 0} \mathrm{m}$ or less as a function of annulus thickness, keeping the inner radius constant at $15 \mathrm{~m}$. (f) The same as (e), but with the inner radius varying and the thickness constant at $5 \mathrm{~m}$.

steep depressions that may represent cave openings. The TPI measures elevational contrast in the DEM. For each focal cell, the TPI is the difference between the elevation of the focal cell and the average elevation of all the cells in the neighborhood (Fig. 2). We used an annulus shape to define the neighborhood, i.e., cells whose center points fall between inner and outer radii. The annulus shape amplifies the difference between the focal cell and the surrounding ring.

Rasters (pixels or grid cells) with TPI values $\leq-10 \mathrm{~m}$ were segmented or partitioned in the DEM image as potential cave entrances (Fig. 3). This depth eliminated shallow reservoirs and chultuns previously identified in the area (Hunter-Tate 1994). Chultuns are typically bottleshaped storage chambers about $2 \mathrm{~m}$ deep built by the Maya that may have served functions such as cisterns, storage, or burial sites. Given the vertical direction of the LiDAR pulse, it is unlikely that caves with side or horizontal openings would be conspicuous. Also, because of the horizontal resolution of the DEM, caves with openings smaller than $1 \mathrm{~m}^{2}$ would most likely not be detected. Several of the previously unrecorded depressions were verified in the field during the spring of 2010.

Within a cave, terrestrial laser scanning has been shown to be an effective method to record cave morphology (González-Aguilera et al., 2009; Lerma et al., 2010). Here we apply this general technique at a coarser scale to measure the shapes of depressions that may represent cave entrances. In addition to locating steep elevational gradients, the TPI was used to characterize the geomorphology of the depressions $\geq 10 \mathrm{~m}$ deep located in the 
DEM. From the segmented image, we used ArcGIS (v. 9.3) coupled with Hawth's Analysis Tools (Beyer, 2004) to quantify numerous parameters of the pixels associated with each depression, i.e., average depth, maximum depth, standard error of depth measures (bottom roughness), opening perimeter, opening area. As topographic features are inherently fractal surfaces (Russ, 1994), the TPI measure is a function of the annulus thickness (w) and inner radius (r) of the annulus (Fig. 3). By analyzing the morphologic parameters with differing annulus scales, we can distinguish among conical, cylindrical, and irregular or more complex openings such as multiple connected depressions or saddle backs.

Lastly, an ordination using principal-components analysis was performed on the LiDAR-derived morphologic parameters for vertical depressions $10 \mathrm{~m}$ or more deep. This was done to understand the range of karst depressions that could be detected by LiDAR in the landscape around Caracol as a function of the inner radius and width of the annulus.

\section{Results And Discussion}

\section{Depression Identification and Field Verification}

Sixty-one depressions 10 or more meters deep were identified in the $200 \mathrm{~km}^{2}$ DEM by visually scanning the image from top to bottom and left to right for patches that were deeper (darker) than their surroundings and by using the Topographic Position Index filter. These were fairly well distributed across the Caracol landscape, but were more common in the hilly terrain on the outskirts of the region with the highest concentration of monumental architecture, which is also the hub of the half-dozen causeways that radiate outward. Only one depression, Cohune Ridge Cave, which is west of depression 50 in Figure 1, had been previously known (Feld, 1994). Other known cave openings (Feld, 1994) were either too shallow or were horizontal, and not detected by the LiDAR scan. Five of the previously unrecorded depressions relatively close to the epicenter were located in the field. All had vegetation above the depression that obscured it from traditional passive remote-sensing techniques. Two of these had massive openings, depressions $23\left(1919 \mathrm{~m}^{2}\right)$ and 24 $\left(1550 \mathrm{~m}^{2}\right)$. During this ground verification, we did not take depth and width measurements on the ground for comparison with the LiDAR-derived measurements. The former was inaccessible without vertical equipment; the latter was explored in a cursory fashion and did not appear to contain Maya artifacts. Of the remaining three one was simply a steep rock face adjacent to a hill, one had an opening of $6 \mathrm{~m}^{2}$ and a steep shaft $>15 \mathrm{~m}$ deep that was inaccessible without vertical equipment, and the last one
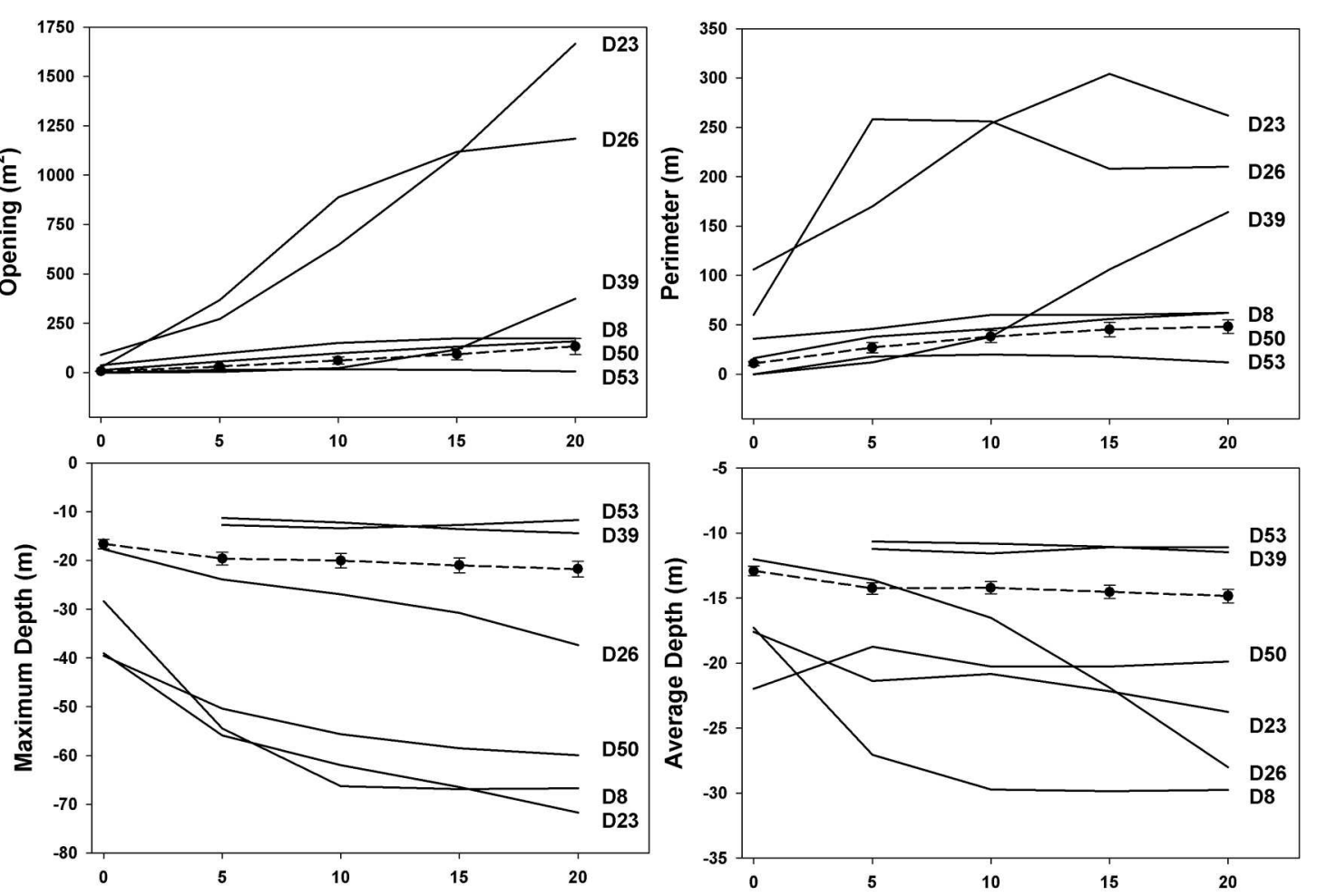

Radius Length (m)

Figure 4. Change in morphologic parameters of selected potential cave opening in Figure 1 derived with TPI from the DEM as a function of inner radius ( $r)$, keeping the annulus thickness constant $(w=5 \mathrm{~m})$. The points on the dashed line are the averages of the 61 depressions at least $10 \mathrm{~m}$ deep, with one standard error indicated. 
DETECTION AND MORPHOLOGIC ANALYSIS OF POTENTIAL BELOW-CANOPY CAVE OPENINGS IN THE KARST LANDSCAPE AROUND THE MAYA POLITY OF CARACOL USING AIRBORNE LiDAR
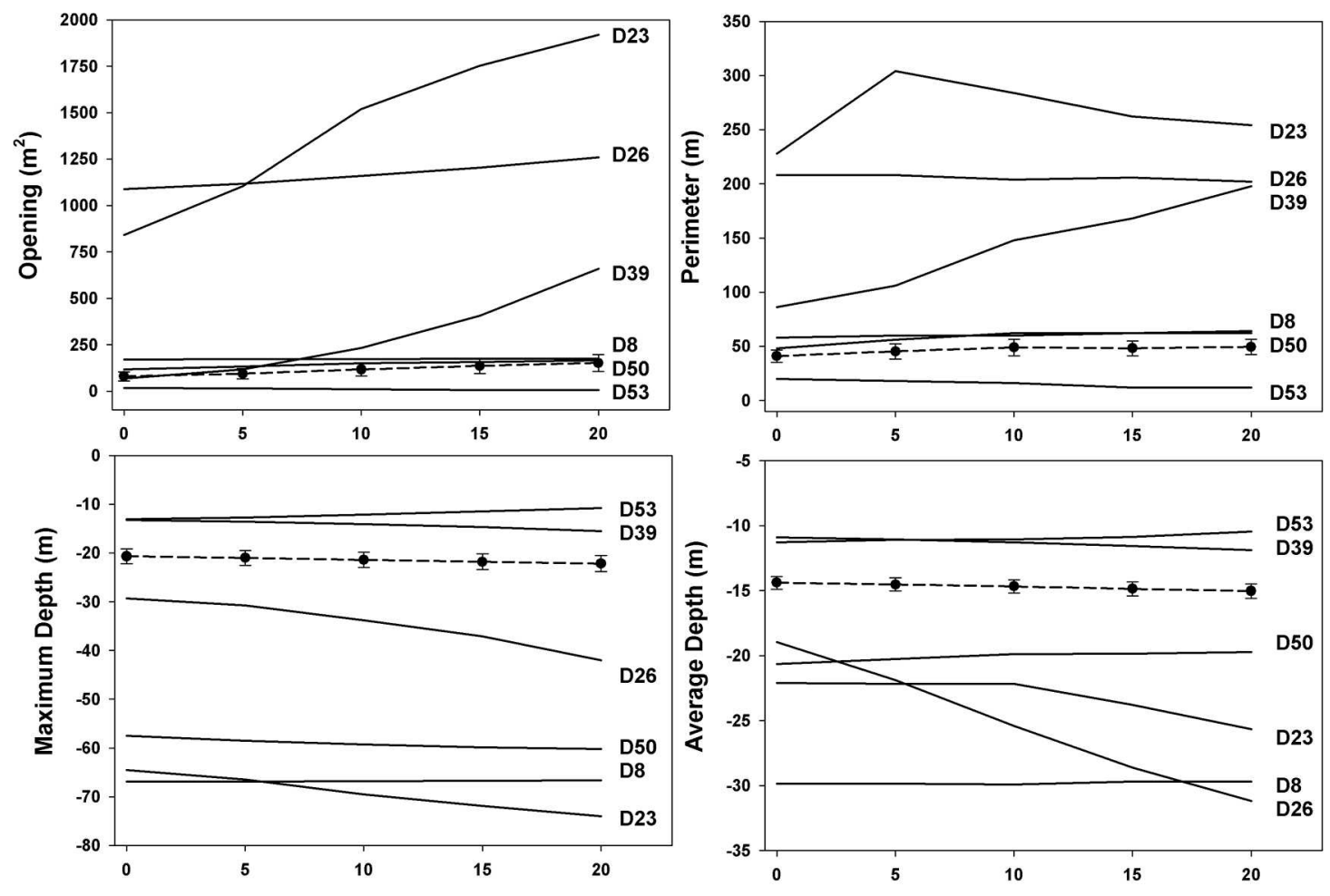

Annulus Width (m)

Figure 5. Change in morphologic parameters of potential cave openings derived with TPI from the DEM as a function of annulus thickness (w) keeping the inner radius constant $(r=15)$. The points on the dashed line are the averages of the 61 depressions at least $m$ deep, with one standard error indicated.

was an accessible cave with an opening of $8 \mathrm{~m}^{2}$. For this cave, the LiDAR detected a maximum depth of $10.9 \mathrm{~m}$. It was explored and found to consist of several rooms with speleothems such as soda straw stalactites, stalagmites, flowstone, and splash cup structures, as well as archaeological features such as human bones and pottery.

\section{Morphologic Characterization}

Based on an annulus thickness of $20 \mathrm{~m}$ and an inner radius of $15 \mathrm{~m}$ (Fig. 4), the average depression opening was $149.3 \mathrm{~m}^{2}\left(\mathrm{SD}=359.8 \mathrm{~m}^{2}\right)$, and the average maximum depth was $21.5 \mathrm{~m}(\mathrm{SD}=13.8)$. Based on an annulus thickness of $5 \mathrm{~m}$ and an inner radius of $20 \mathrm{~m}$ (Fig. 5), the average

Table 1. Eigenvectors associated with the principal component analysis of the LiDAR-derived parameters that characterize the 61 depression morphologies. The numbers in parentheses are the percentages of variance explained by the principal components axes. Slopes are functions of the annulus inner radius $(r ; w=5)$ and thickness $(w ; r=15)$ as shown in Figures 4 and 5.

\begin{tabular}{lccr}
\hline Parameters & PC1 (52.5\%) & PC2 $(22.9 \%)$ & PC3 $(9.1 \%)$ \\
\hline Maximum Depth & -0.23 & -0.36 & 0.32 \\
Average Depth & -0.23 & -0.42 & 0.04 \\
Standard Error of Depth & -0.07 & 0.41 & -0.22 \\
Opening Area & 0.35 & -0.11 & 0.04 \\
Perimeter & 0.35 & -0.16 & -0.06 \\
Slope Max Depth (r) & -0.24 & -0.35 & 0.28 \\
Slope Avg Depth (r) & -0.21 & -0.32 & -0.30 \\
Slope Area (r) & 0.35 & -0.08 & 0.12 \\
Slope Perimeter (r) & 0.30 & -0.29 & -0.11 \\
Slope Max Depth (w) & -0.32 & -0.00 & -0.26 \\
Slope Avg Depth (w) & -0.26 & -0.03 & -0.58 \\
Slope Area (w) & 0.30 & -0.24 & -0.20 \\
Slope Perimeter (w) & 0.12 & -0.34 & -0.39 \\
\hline
\end{tabular}




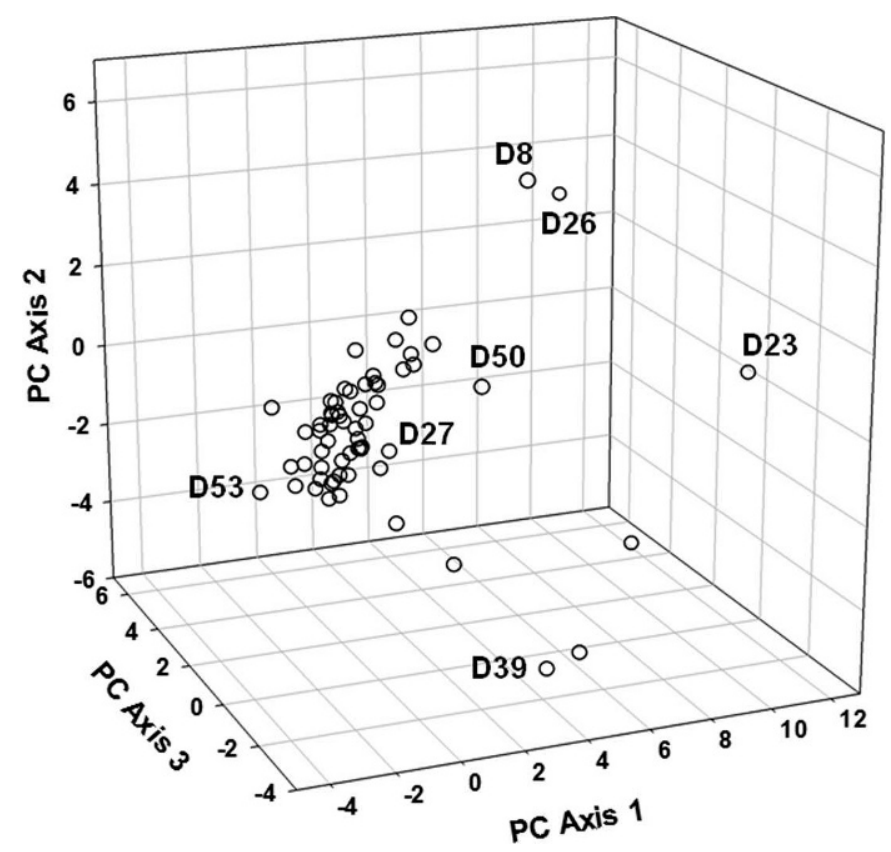

Figure 6. Ordination of depressions based on morphological characters derived using TPI for different scales of annulus width and radius length. The numbered markers correspond to depressions on Figure 1 that represent the extremities for the three principal component axes except number 27 , which corresponds to the depression whose morphology most resembled the mean.

depression opening was $130.4 \mathrm{~m}^{2}(\mathrm{SD}=313.5)$; the average maximum depth was $21.1 \mathrm{~m}(\mathrm{SD}=13.5)$. The general trends with increasing annulus thickness (holding the inner radius constant at $15 \mathrm{~m}$ ) and inner radius (holding the thickness constant at $5 \mathrm{~m}$ ) showed slight increases in opening area and perimeter length and slight increases in maximum and average depths (Figs. 4 and 5). However, these effects varied substantially for individual depressions.

The first three principal components (PC) axes accounted for $84.5 \%$ of the variance (Table 1). The first
PC axis was positively weighted on parameters that characterized the morphology of the depressions' opening, its area and perimeter. The second PC axis was negatively weighted on parameters that characterized the depressions' average and maximum depth and standard error of depth. The third PC axis was negatively weighted on parameters that are related to scaling effects, i.e., slopes of parameter measures as a function of $\mathrm{r}$ and $\mathrm{w}$. The ordination showed little distinct grouping of depression morphologies (Fig. 6). All but about ten of these depression morphologies were concentrated slightly on the negative side of PC Axis 1 and near the zero intercept of PC Axis 2 and PC Axis 3. This implies that the depressions tend to be smaller than the average, which is probably skewed by the few much larger depressions. D27, the depression closest to the average of the 61 depressions, based on their positions in the ordination space, had an average depth of $13.2 \mathrm{~m}(13.5 \mathrm{~m})$, a maximum depth of $25.3 \mathrm{~m}(24.8 \mathrm{~m})$, and an opening of $86 \mathrm{~m}^{2}\left(67 \mathrm{~m}^{2}\right)$ with $\mathrm{r}=20 \mathrm{~m}$ and $\mathrm{w}=15 \mathrm{~m}(\mathrm{r}=5 \mathrm{~m}$ and $\mathrm{w}$ $=20 \mathrm{~m}$ ). The hillshaded rendering of this nearly average depression is shown in Figure 7. The irregular bottom is the cause of the discrepancy between the average and maximum depths. Its conical shape resulted in its opening area and maximum depth being related to the scale of both the annulus width and radius length.

The depressions with extreme morphologies, as represented by the PC axes, are rendered in Figure 8 . The first PC axis shows two depressions that are distinguished by opening area; D53 has an opening of $5 \mathrm{~m}^{2}$ and D23 has an opening of $1919 \mathrm{~m}^{2}$ when analyzed with an annulus thickness of $20 \mathrm{~m}$ and inner radius of $15 \mathrm{~m}$. The second PC axis juxtaposes a narrow, deep D8 and a broad, shallow D39. The standard error of the depth measure is among the highest and lowest for D8 and D39, respectively. The third PC axis contrasts a slightly slanted, flat-sided D26 and a complex, sharply recessed D50. Average depth increased for D26 and decreased for D50 with increasing annulus thickness. The decrease for D50 was unusual and the greatest among the 61 depressions.

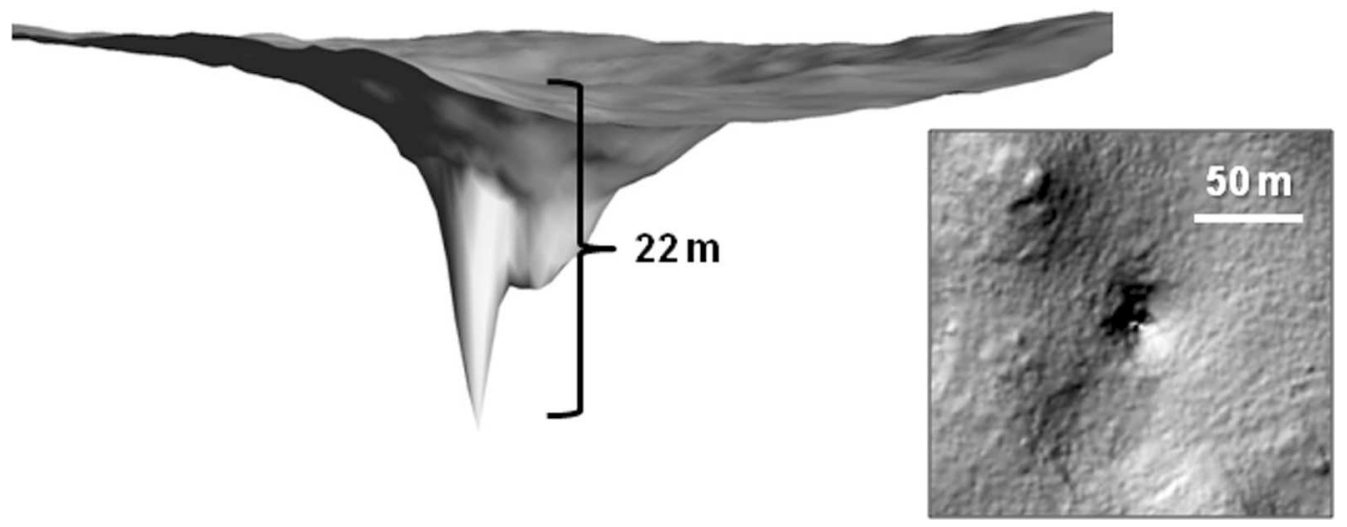

Figure 7. Bare-earth 3-D rendering and top-down view of depression 27, the one with the most typical morphology, closest to the centroid of the 61 depressions in the volume defined by the three principal component axes of ordination space (Fig. 6). 


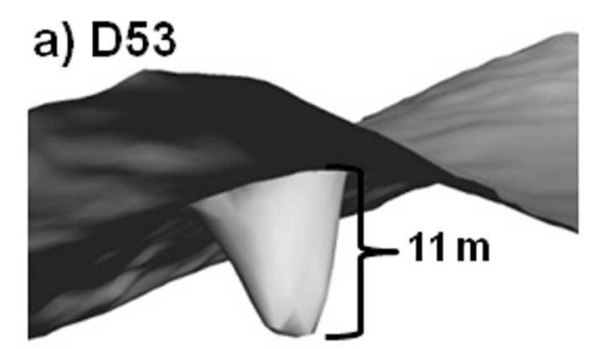

\section{c) D8}
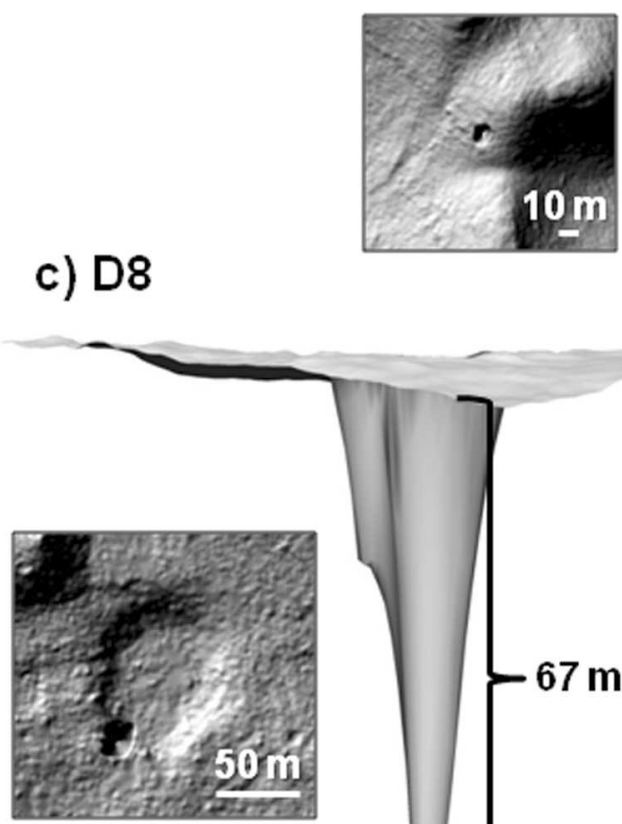

e) D26

\section{b) D23}

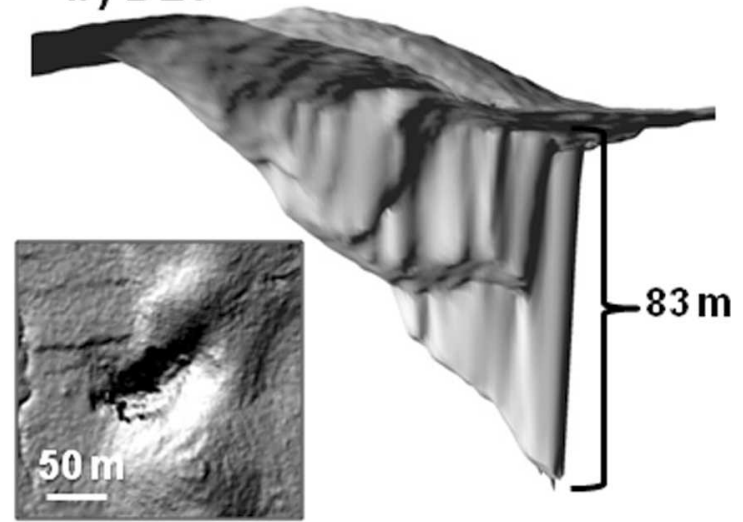

d) D39

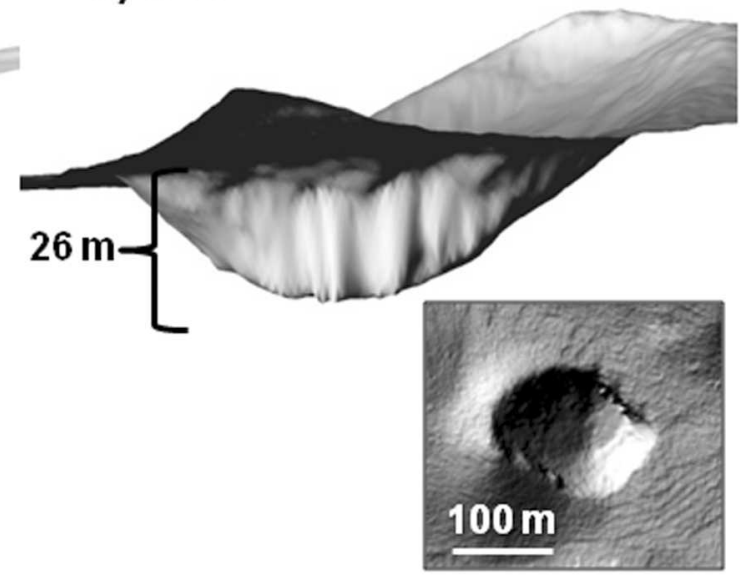

f) $\mathrm{D} 50$
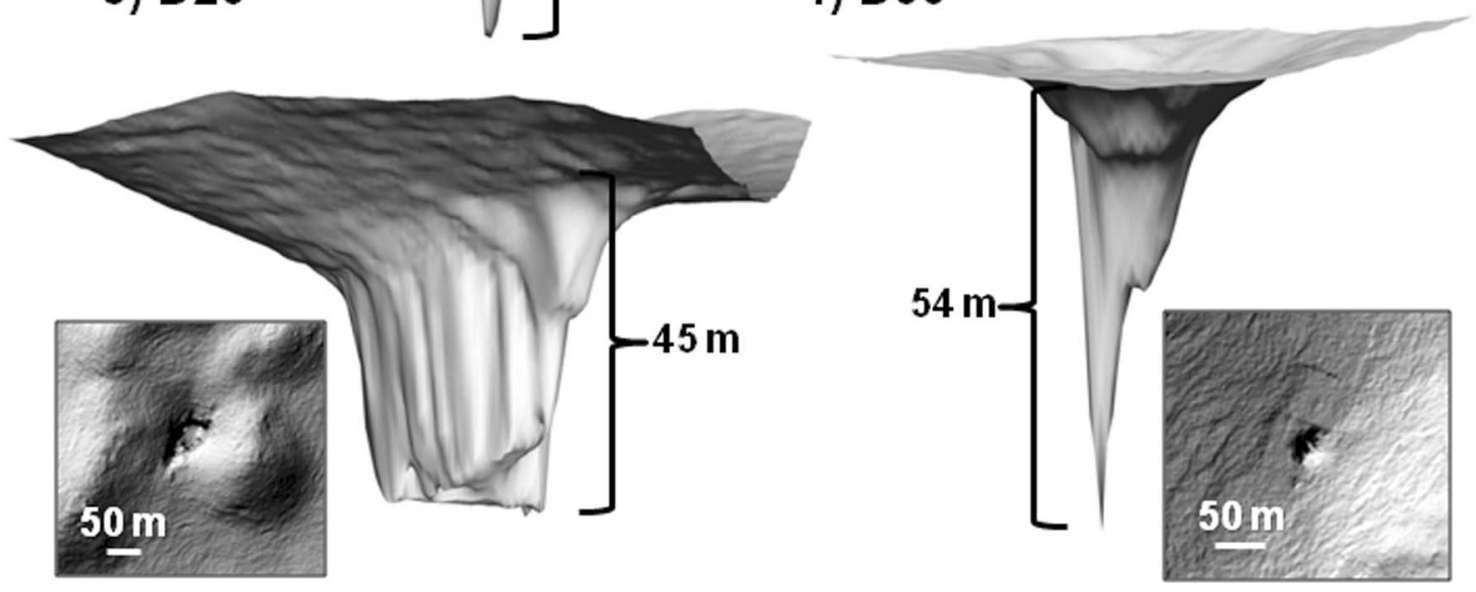

Figure 8. Morphologies of some depressions at the extremes in the three ordination axes (Fig. 6). Hillshaded 3-D renderings and top-down views of depression 53 juxtaposed with depression 23 for PC Axis 1, depression 8 juxtaposed with depression 39 for PC Axis 2, and depression 26 juxtaposed with depression 50 for PC Axis3.

This type of morphological analysis shows the range of shapes and sizes of the depressions and provides some level of guidance for future exploration; it may help indicate how the depression was formed and provide information as to the historic accessibility of the depression for the ancient Maya, as well as for current archaeologists.

\section{Conclusions}

Remote sensing of geomorphological features in a karst landscape is not particularly novel (e.g., Siart et al., 2009); however, detecting fine-scale (1 $\mathrm{m}$ horizontal resolution) karstic features across a densely forested landscape as 
described here is unprecedented. Through this airborne LiDAR study, we detected 60 previously undocumented vertical depressions, shafts, and cave entrances that pockmark the karstic landscape beneath the dense rainforest canopy of western Belize. This study demonstrates the capability of LiDAR to detect surface features that may represent entrances to subterranean geological complexes. As prospecting for openings is often laborious, timeconsuming work, this application of LiDAR should improve the efficiency of cave location. However, as many caves used by the Maya have horizontal or very small openings, ground searches on foot are necessary for a comprehensive inventory.

Though there are several ways to partition DEM landscapes into a variety of terrain types (e.g., Yokoyama et al., 2002; Denizman, 2003; Iwahashi and Pike, 2007; Stepinski and Bagaria, 2009; Patel and Sarkar, 2010; Prima and Yoshida, 2010), the Topographic Position Index seemed effective at locating and quantifying the geomorphology of these recessed features. Somewhat unexpectedly, the LiDAR sensor system flying at an altitude of nearly $1 \mathrm{~km}$ was able to record a variety of geomorphologies from these vertical depressions. This rich dataset shows some of these depressions to be very deep $(>50 \mathrm{~m})$ with massive openings ( $>350 \mathrm{~m}$ across); others are deep $(>25 \mathrm{~m})$ with relatively narrow ( $<5 \mathrm{~m}$ across) openings. Most of these depressions represent caves that were contemporary with the ancient Maya and likely contain artifacts, but a few may be more recent. As only a tenth of these depressions have been located and explored on the ground, it is important that these potentially culturally significant sites remain undisturbed until their archaeological context can be realized.

\section{ACKNOWLEDGMENTS}

This research was supported by NASA Grant \#NNX08AM11G through the Space Archaeology program and the University of Central Florida-University of Florida-Space Research Initiative (UCF-UF-SRI). We appreciated conversations with Jaime Awe, Holley Moyes, and Cameron Griffith, members of the Western Belize Regional Cave Project (WBRCP), about caving and cave detection using remote sensing techniques in Belize. The expertise of James Angelo with Fusion and the National Center for Airborne Laser Mapping (NCALM), Ramesh Shrestha, Clint Slatton, Bill Carter, and Michael Sartori, helped to make this study possible.

\section{REFERENCES}

Allee, W.C., 1926, Measurement of environmental factors in the tropical rain-forest of Panama, Ecology, v. 7, p. 273-302.

Beyer, H.L., 2004, Hawth's Analysis Tools for ArcGIS, available at: www. spatialecology.com/htools, [accessed September 24, 2010].

Brady, J.E., and Prufer, K.M., 2005, In the Maw of the Earth Monster: Mesoamerican Ritual Cave Use: Austin, University of Texas Press, $438 \mathrm{p}$.
Brokaw, N.V.L., 1992, Vegetation and tree flora in the central area of the Caracol archaeological reserve, Belize: Manomet, Massachusetts, Manomet Observatory for Conservation Science, $28 \mathrm{p}$.

Carter, W., Shrestha, R., Tuell, G., Bloomquist, D., and Sartori, M., 2001, Airborne laser swath mapping shines new light on Earth's topography: Eos, v. $82,549,550,555$ p.

Chase A.F., 1988, Jungle surveying: mapping the archaeological site of Caracol, Belize: Point of Beginning, v. 13, p. 10-24.

Chase, A.F., and Chase, D.Z., 1996, A mighty Maya nation: how Caracol built an empire by cultivating its 'middle class': Archaeology, v. 49, p. $66-72$

Chase, A.F., and Chase, D.Z., 2001, Ancient Maya causeways and site organization at Caracol, Belize: Ancient Mesoamerica, v. 12, p. 273-281.

Chase, A.F., Chase, D.Z., and Weishampel, J.F., 2010, Lasers in the jungle: airborne sensors reveal a vast Maya landscape: Archaeology, v. 63 , no. 4 , p. $27-29$.

Chase, A.F., Chase, D.Z., Weishampel, J.F., Drake, J.B., Shrestha, R.L., Slatton, K.C., Awe, J.J., and Carter, W.E., 2011, Airborne LiDAR, archaeology, and the ancient Maya landscape at Caracol, Belize: Journal of Archaeological Science, v. 38, p. 387-398. doi: 10.1016/ j.jas.2010.09.018.

Cushing, G.E., Titus, T.N., Wynne, J.J., and Christensen, P.R., 2007, THEMIS observes possible cave skylights on Mars: Geophysical Research Letters, v. 34, L17201 p. doi: 10.1029/2007GL030709.

Denizman, C., 2003, Morphometric and spatial distribution parameters of karstic depressions, lower Suwanee River basin, Florida: Journal of Cave and Karst Studies, v. 65, p. 29-35.

Feld, W.A., 1994, The caves of Caracol: initial impressions, in Chase, D.Z., and Chase, A.F., eds., Studies in the archaeology of Caracol, Belize. San Francisco, Pre-Columbian Art Research Institute Monograph 7, p. 76-82.

Gallagher, J.M., and Josephs, R.L., 2008, Using LiDAR to detect cultural resources in a forested environment: an example from Isle Royale National Park, Michigan, USA: Archaeological Prospection, v. 15, p. 187-206. doi: 10.1002/arp.333.

González-Aguilera, D., Muñoz-Nieto, A., Gómez-Lahoz, J., HerreroPascual, J., and Gutierrez-Alonso, G., 2009, 3D digital surveying and modeling of cave geometry: application to Paleolithic rock art: Sensors, v. 9, p. 1108-1127. doi: 10.3390/s90201108.

Griffith, C., 2000, Remote sensing in cave research, available at: www. archaeology.org/online/features/belize/remote.html, [accessed September 24, 2010].

Griffith, C., 2001, Locating Cave Sites: Results of our remote-sensing research, available at: www.archaeology.org/interactive/belize/newremote. html, [accessed March 2, 2011].

Guisan, A., Weiss, S.B., and Weiss, A.D., 1999, GLM versus CCA spatial modeling of plant species distribution: Plant Ecology, v. 143, p. 107122. doi: 10.1023/A:1009841519580.

Hofton, M.A., Rocchio, L.E., Blair, J.B., and Dubayah, R., 2002, Validation of vegetation canopy lidar sub-canopy topography measurements for a dense tropical forest: Journal of Geodynamics, v. 34, p. 491-502. doi: 10.1016/S0264-3707(02)00046-7.

Hunter-Tate, C.C., 1994, The chultuns of Caracol, in Chase, D.Z., and Chase, A.F., eds., Studies in the archaeology of Caracol, Belize. San Francisco, Pre-Columbian Art Research Institute Monograph 7, p. 64-75.

Iwahashi, J., and Pike, R.J., 2007, Automated classifications of topography from DEMs by an unsupervised nested-means algorithm and a three-part geometric signature: Geomorphology, v. 86, p. 409 440. doi: 10.1016/j.geomorph.2006.09.012.

Jenness, J., Brost, B., and Beier, P., 2010, Land Facet Corridor Designer, available at: www.jannessent.com/downloads/LandFacetCorredor. zip, [accessed September 24, 2010].

Lerma, J.L., Navarro, S., Cabrelles, M., and Villaverde, V., 2010, Terrestrial laser scanning and close range photogrammetry for 3D archaeological documentation: the Upper Palaeolithic cave of Parpalló as a case study: Journal of Archaeological Science, v. 37, p. 499-507. doi: 10.1016/j.jas.2009.10.011.

McNatt, L., 1996, Cave archaeology of Belize: Journal of Cave and Karst Studies, v. 58, p. 81-99.

Miller, T., 1990, Caves and caving in Belize, Caves and Caving, no. 49, p. $2-4$.

Journal of Cave and Karst Studies, December 2011 195 
Moyes, H., 2002, The use of GIS in the spatial analysis of an archaeological cave site: Journal of Cave and Karst Studies, v. 64, p. 9-16.

Patel, P.P., and Sarkar, A., 2010, Terrain characterization using SRTM data: Journal of Indian Society of Remote Sensing, v. 38, p. 11-24. doi: 10.1007/s12524-010-0008-8.

Pendergast, D.M., 1969, The Prehistory of Actun Balam, British Honduras: Toronto, Royal Ontario Museum Occasional Paper 16, Art and Archaeology, $68 \mathrm{p}$.

Pendergast, D.M., 1970, A. H. Anderson's Excavations at Rio Frio Cave E, British Honduras (Belize): Toronto, University of Toronto, Royal Ontario Museum Occasional Paper 20, Art and Archaeology, 59 p.

Pendergast, D.M., and Savage, H.G., 1971, Excavations at Eduardo Quiroz Cave British Honduras (Belize): Toronto, University of Toronto, Royal Ontario Museum Occasional Paper 21, Art and Archaeology, $123 \mathrm{p}$.

Prima, O.D.A., and Yoshida, T., 2010, Characterization of volcanic geomorphology and geology by slope and topographic openness: Geomorphology, v. 118, p. 22-32. doi: 10.1016/j.geomorph.2009. 12.005 .

Prufer, K.M., and Brady, J.E., 2005, Stone Houses and Earth Lords: Maya Religion in the Cave Context: Boulder, University Press of Colorado, $392 \mathrm{p}$.

Reeder, P., Brady, J.E., and Webster, J., 1998, Geoarchaeological investigations on the northern Vaca Plateau, Belize: Mexicon, v. 20, p. $37-41$.

Ricketson, O. Jr., and Kidder, A.V., 1930, An archaeological reconnaissance by air in Central America: Geographical Review, v. 20, p. $177-206$.

Russ, J.C., 1994, Fractal Surfaces, New York, Plenum Press, 309 p.

Sellers, B., and Chamberlain, A., 1998, Cave detection using ground penetrating radar: The Archaeologist, no. 31, p. 20-21.

Siart, C., Bubenser, O., and Eitel, B., 2009, Combining digital elevation data (SRTM/ASTER), high resolution satellite imagery (Quickbird) and GIS for geomorphological mapping: A multi-component case study on Mediterranean karst in Central Crete: Geomorphology, v. 112, p. 106-121. doi: 10.1016/j.geomorph.2009.05.010.

Stepinski, T.F., and Bagaria, C., 2009, Segmentation-based unsupervised terrain classification for generation of physiographic maps: IEEE Geoscience and Remote Sensing Letters, v. 6, p. 733-737. doi: 10.1109/LGRS.2009.2024333.

Weishampel, J.F., Blair, J.B., Dubayah, R., Clark, D.B., and Knox, R.G., 2000a, Canopy topography of an old-growth tropical rainforest landscape: Selbyana, 21, p. 79-87.

Weishampel, J.F., Blair, J.B., Knox, R.G., Dubayah, R., and Clark, D.B., $2000 \mathrm{~b}$, Volumetric lidar return patterns from an old-growth tropical rainforest canopy: International Journal of Remote Sensing, v. 21, p. 409-415. doi: 10.1080/014311600210939.

Weishampel, J.F., Chase, A.F., Chase, D.Z., Drake, J.B., Shrestha, R.L., Slatton, K.C., Awe, J.J., Hightower, J., and Angelo, J., 2010, Remote sensing of ancient Maya land use features at Caracol, Belize related to tropical rainforest structure, in Forte, M., Campana, S., and Liuzza, C., eds., Space, Time, Place: Third International Conference on Remote Sensing Archaeology: Oxford, Archaeopress, BAR International Series 2118, p. 45-52.

Weiss, A., 2001, Topographic position and landform analysis, available at: www.jennessent.com/downloads/TPI-poster-TNC_18x22.pdf, [accessed September 24, 2010].

Wynne, J.J., Titus, T.N., and Diaz, G.C., 2008, On developing thermal cave detection techniques for earth, the moon and mars: Earth and Planetary Science Letters, v. 272, p. 240-250. doi: 10.1016/j.eps1. 2008.04.037.

Yokoyama, R., Shirawawa, M., and Pike, R.J., 2002, Visualizing topography by openness: a new application of image processing to digital elevation models: Photogrammetric Engineering \& Remote Sensing, v. 68, p. 257-265. 